Saeculum Christianum

vol. XXII (2015)

pp. $80-90$

\title{
THE ECONOMIC AND FOUNDATION ACTIVITY OF JAN OF PILCZA (CA. 1405-1476), THE CASTELLAN OF CRACOW. THE PROFILE AGAINST THE BACKGROUND OF THE SELECTED IUNIORES FACTION REPRESENTATIVES' ACTIVITY
}

The history of the informal magnate factions' activity constitutes one of the most important factors shaping the image of the political history of the Crown of the Kingdom of Poland. The issue of the rivalry between the supporters of Bishop Zbigniew Oleśnicki and the faction of magnates, formed by the confederates of Spytko of Melsztyn of 1439, remembered as juniors thanks to Jan Długosz, remains worthy of historians' attention in the context of research into the Middle Ages. While attempting to describe the history of the iuniores faction, the condition and economic activity of its members is also worth tackling besides the political issues. The analysis of the indicated spheres of life is a key factor in understanding the position occupied by the representatives of the former young nobility camp in the society of the Crown of the Kingdom of Poland in the 15th century. Despite a significant diversification of the material status of particular representatives of the indicated group, one may be tempted to take a synthetic look and make observations, which to some extent turn out to be common to the main core of the iuniores faction. An important section of the late medieval magnates' activity was undoubtedly the one of the foundation character. The reflections on the aforementioned issue constitute an inseparable element of prosopographic research. Therefore, the indicated sphere of life of nobility cannot be ignored through covering it with political activity in biographies. Nor should attempts be made to construe the picture of the iuniores faction without a general overview of the most important foundations created by its members.

Unfortunately, there is no synthesis of general characteristics regarding economic and foundation activities of iuniores in the contemporary studies on the history of magnates from the circle thereof ${ }^{1}$. In the aforementioned context, an attempt to confront this type of activity, undertaken by one of the juniors, with general characteristics of the activity conducted by selected representatives of the faction, may turn out to be valuable. A representative figure

\footnotetext{
* Translated by Spektra Sp. z o.o.

1 The following article is worth noting among more recent publications on the faction of iuniores J. Sperka, B. Czwojdrak, Konfederaci Spytka z Melsztyna z roku 1439, in: Króla a prawo stanów do oporu, eds. M. Markiewicz, E. Opaliński, R. Skowron, Kraków 2010 pp. 89-104.
} 
in the indicated context, still rarely present in studies on the Polish 15th century nobility, was the Castellan of Cracow, Jan of Pilcza. He constitutes one of clearer examples of social and political advancement of the iuniores' members during the reign of kings Władysław III and Kazimierz Jagiellończyk. The political adversary of the bishop Zbigniew Oleśnicki, a signatory of the confederation act of Spytko of Melsztyn of 1439, the son of Queen Elżbieta Granowska, occupying the highest offices in the Crown in his career, seems to be a good example of a young nobleman from Małopolska who, implementing the political programme of the iuniores faction, entered the circle of the closest co-workers of the ruler. Basing on that, it is worth taking a closer look at the history of his economic and foundation activities and making an attempt to relate the results of the observations to the activity conducted by other juniors.

The Genesis of the iuniores faction itself, whose member was Jan of Pilcza, bases to a certain extent on economic factors. Young members of the distinguished, often very rich families of the Crown, ousted from influences in the country along with strengthening of the political position of bishop Oleśnicki, started to experience the deterioration of their financial situation $^{2}$. It was the result of, inter alia, the reduction of their land estates, as in the case of Spytko of Melsztyn ${ }^{3}$. With the development of the indicated phenomenon, the level of income of groups affected by Oleśnicki’s policy dramatically decreased. Frustration and limitation of financial profits were also generated by the ousting of juniors from the paths of promotion to higher land and central offices, once held by their fathers and grandfathers. Both factors were linked to a slow impoverishment of the indicated part of nobility. Its activity could only be based on the family land estates, not always generating income at the expected level.

With the ascension of Władysław III to the Polish throne, the political importance of iuniores grew slowly. Their financial situation, which allowed them to develop their economic activity, began to improve as well. The most significant strengthening of the position of the former iuniores took place after the acceptance of the Polish Crown by Kazimierz Jagiellończyk ${ }^{4}$. Thanks to various benefits given to royal allies, in addition to political influence, their income also increased. It was not uncommon in the Times of Kazimierz to lease the royal lands, which also generated considerable income. Despite this, however, the main axis of economic activity for the rising group of magnates was still constituted by their family property. Based on their surroundings, they carried out a colonisation activity, locating towns and villages tied by relations of ancillary nature.

Additionally, the economic activity of Jan of Pilcza was to a large extent based on income from his properties. They included primarily the estates in the Przemyśl region i.e. Łańcut, Kańczuga, the district of Tyczyn and the lands of the Pilica district with the town of Pilica at the forefront. The latter one, from which the Pilecki family took the surname, incorporated the castle in Smolen, Stara Pilica, Nowa Pilica, Bydlin and about 20 villages with granges. Apart from Tyczyn, the district of Tyczyn covered about 18 villages. The estates of Łańcut

\footnotetext{
2 See: A. Sochacka, Konfederacja Spytka z Melsztyna z 1439 r. - rozgrywka polityczna czy ruch ideologiczny?, „Rocznik Lubelski”, 16, Lublin 1973, pp. 41-66.

3 W. Dworzaczek, Leliwici Tarnowscy. Z dziejów możnowładztwa małopolskiego wiek XIV-XV, Warszawa 1971, p. 141 .

4 See: W. Fałkowski, Elita władzy w Polsce za panowania Kazimierza Jagiellończyka (1447-1492), Warszawa 1992.
} 
and Kańczuga comprised jointly about 20 villages ${ }^{5}$. Thus, the mere state of possessing such a large number of land estates, given the conditions at that time, placed Pilecki among the relatively wealthy people. It provides a reason to reflect on the economic management of the indicated estates. In this context, it is also legitimate to compare the action undertaken in this respect by Castellan Jan of Pilcza with a certain model of undertakings of the former members of the young nobility faction.

Despite the fact that there was no real possibility of obtaining an ordinance privilege at the time of Jan of Pilcza, it is worth noting that he tried to consolidate his assets. It is clearly exemplified by Tyczyn, which thanks to the efforts of Pilecki, over time became a part of the Przemyśl region, with a number of towns remaining his property ${ }^{6}$. As a result of his marriage to Jadwiga Kurowska and a divison of inheritance after the death of Piotr, his father-n-law, Jan came into possession of part of Kurów, Krzczonów, and Rzemienowice, located in the Wiślica region? ${ }^{7}$. The scale of Pilecki's economic activity is also reflected in the statements of receivables. For example, Jan of Pilcza was the most indebted landowner in the Przemyśl region in the middle of the 15 th century ${ }^{8}$. Taking out loans or granting thereof was necessary to Pilecki for conducting both political and economic activities. The fact that Jan of Pilcza was one of the main trustees and lenders of Kazimierz Jagiellończyk, and earlier of Władysław III, proves his abilities and freedom in capital trading. Financial contacts shaped good relations with the ruler, which may be evidenced by a royal document releasing Jan of Pilcza from the guarantee of 753 florins, which he granted to Piotr Odrowąż on behalf of the monarch ${ }^{9}$. Pilecki used the services of Cracow bourgeois families to trade in loans. To exemplify that, the loan, amounting to 2000 Hungarian florins, granted by Pilecki to the king in 1461, is worth quoting. He did that with the help of the Morsztyn family, remaining the leaseholder of salt mines at that time ${ }^{10}$. The activity of iuniores around the salt mining seems to be symptomatic. It can be confirmed by a joint initiative of giving financial support to the miner, Mikołaj Serafin, by Andrzej Tęczyński, Jan Czyżowski and Jan Koniecpolski. The iuniores were probably willing to stop the growing competitiveness of salt imported to the Crown from the territory of the Teuton State ${ }^{11}$. It is worth noting that the magnates, who often differed significantly in their views on the internal policy issues, were able to take joint action which was beneficial not only to themselves but also to the state. Over time, Tęczyński himself became the owner of mining rights, which entitled him to participate in the income from the exploitation of the aforementioned salt mines, developed

\footnotetext{
5 E. Wac, Kilka uwag o działalności gospodarczej panów z Pilicy w XIV-XVI wieku, „Annales Academiae Paedagogicae Cracoviensis. Studia Historica”, 3/2004, Kraków 2004, p. 479; F. Kiryk, S. Matuszew, Zarys dziejów Tyczyna do roku 1772, in: 600 lat Tyczyna (1368-1968), ed. T. Kowalski, Rzeszów 1973, p. 113.

6 Ibid, pp. 45-60.

7 Joannis Dtugosz senioris canonici cracoviensis - Liber Beneficiorum diocesis cracoviensis, vol. 1, ed. A. Przeździecki, Kraków 1863, p. 53.

$8 \quad$ M. Ungeheuer, Stosunki kredytowe w ziemi przemyskiej w połowie XV wieku, Lwów 1929, p. 198.

9 Zbiór dokumentów małopolskich (hereinafter ZDM), 5, ed. S. Kuraś, Wrocław 1970, No. 1465.

10 Matricularum Regni Poloniae Summaria (hereinafter MRPS), 1, ed. T. Wierzbowski, Warszawa 1905, No. 578; S. Krzyżanowski, Morsztynowie w XV wieku, „Rocznik Krakowski”, vol. 1, Kraków 1898, pp. 326-358; J. Piotrowicz, Rozwój żup krakowskich w średniowieczu, in: Dzieje żup krakowskich, ed. R. Kędra, Wieliczka 1988, pp. 142-143 .

11 S. Gawęda, Możnowładztwo małopolskie w XIV $i$ w pierwszej połowie XV wieku: Studium z dziejów rozwoju wielkiej własności ziemskiej, Kraków 1966, p. 108.
} 
by him by the improvement of mining methods ${ }^{12}$. In 1459, Hińcza of Rogów, who with his actions prevented the deepening of crisis in the area of salt trade, also became one of the leaseholders of salt mines ${ }^{13}$.

In managing his properties, Jan of Pilcza paid attention to, inter alia, trade, which he tried to develop, by obtaining further privileges to organise fairs in his towns. The most representative examples in this respect are the privileges for Tyczyn and Łańcut. The first one, obtained on 14 August 1447, determined the date of Tyczyn fair for the Corpus Christi Feast $^{14}$. The records of the document allowed, among others, many types of merchants to participate in the fair ${ }^{15}$. Such attitude towards the issue of trade regulations facilitated rapid development of towns. The Łańcut privilege was obtained by Jan of Pilcza on 24 June 1448 during a convention in Lublin. It established that an annual fair in Lańcut was to be held a week before St. Adalbert's Day ${ }^{16}$. A similar privilege, entered in the Crown certificate, was obtained by Pilecki for Kańczuga in $1473^{17}$. It may show that Jan of Pilcza cared for adequate economic security as regards his estates. Thanks to the records of privileges for his town, it is also known that Pilecki contributed to the development of trade in his towns by not limiting foreign settlements there.

Jan of Pilcza paid a lot of attention to the issue of mining and iron industry. It is worth noting that the presence and functioning of mines in a given region influenced its general economic condition and facilitated the development of the region. Pilecki owned, among others, two iron smithies in the villages of Blanowice - near Zawiercie and Krzemienida near Siewierz, and also lead mines in Strzegowa and Złożeniec ${ }^{18}$. The indicated branches of economy, developing at that time, had direct impact on the Crown's defence capabilities. It seems therefore right to state that through proper management of those objects, Jan of Pilcza contributed to the improvement of the internal situation of the state, fulfilling his duties for its benefit.

With the improvement of their political status, other members of the faction of iuniores started to rebuild the material status of their families as well. The possessions of the iuniores, apart from the hereditary parts, based on, inter alia, the bestowals from the starosty estates. It may be exemplified by the activity of Dziersław Rytwiański, who obtained huge profits from being the Staroste of Sandomierz by $1477^{19}$. The properties in Chęcin and Zwolen brought huge profits to Hińcza of Rogów ${ }^{20}$, whereas Mikołaj of Brzezie gained profit from the starosty

\footnotetext{
12 Ibid, p. 107.

13 J. Piotrowicz, op. cit., p. 145.

14 MRPS, 1, Warszawa 1905, No. 5; Stownik historyczno-geograficzny ziemi sanockiej w średniowieczu, p. 3, elab. A. Festnacht, Kraków 2002, p. 200.

15 Matricularum Regni Poloniae Codices Saeculo XV Conscripti, 1, ed. W. Graniczny, A. Mysłowski, Warszawa 1914, No. 33.

16 MRPS, 1, Warszawa 1905, No. 18.

17 Ibid, No. 973.

18 E. Wac, op. cit., p. 479.

19 B. Czwojdrak, Jastrzębce w ziemi krakowskiej i sandomierskiej do połowy XV wieku, Kraków 2007, pp. 120-121; J. Wroniszewski, Tenuty i tenutariusze w średniowiecznym województwie sandomierskim, in: Dwór a kraj. Między centrum a peryferiami władzy, ed. R. Skowron, Kraków 2003, p. 56.

20 Ibid, p. 50.
} 
in Dobrzyca ${ }^{21}$. The indicated examples reinforce the conclusion on the existence of a close link between the development of political career and the economic and financial activity of magnates in the late Middle Ages. With the enlargement of the properties of iuniores, the number of private castles, built both as family residencies and defence fortresses, grew. As far as the activities of the members of the young nobility are concerned, the aforementioned process reached its peak after Kazimierz Jagiellończyk ascended the throne. At that time, the ruler approved of the plans to build new castles and modernise the existing ones, especially those located near the borders of the state ${ }^{22}$. An example from the circle of iuniores may be in this case the family of Kmita and their castles in Wiśnicz and Sobieńn ${ }^{23}$.

An important factor affecting the situation of nobility in general, and therefore also the young nobility representatives, were the royal property endowments. The indicated financial relation between the king and Jan of Pilcza is evidenced by the records on his properties. It may be illustrated by the grant of 40 Hungarian florins made by Kazimierz Jagiellończyk in 1473 on the Zamszany lands, belonging to Pilecki ${ }^{24}$. It should be observed here that until the middle of the century there can be no talk on the monarchs favouring or distinguishing iuniores in this matter. In order to picture the phenomenon, two examples are worth quoting. By 1450, Mikołaj Lanckoroński of Brzezie together with his brother Jan, who held high government offices during the reign of Kazimierz Jagiellończyk, were bestowed only one castle, one town and 11 villages. One of the most important figures of the iuniores faction, who later co-created the royal camp, Dziersław of Rytwian was not granted any bestowal. However, he had a significant number of 41 villages $^{25}$. Much more attention was paid by the iuniores to the development of their family estates and the towns located on their territory. One of the ways to ensure economic growth of a given centre was the bestowal of German rights. The members of the young nobility faction did not keep off the indicated procedure. It can be illustrated by the case of Piotr of Kurów, who granted a modern municipal charter to Bochotnica in $1442^{26}$.

The short outline illustrates the broad spectrum of economic activities of iuniores. The indicated case draws attention to a diverse character of undertaken actions. In addition to the development of already owned properties, iuniores largely sought to expand their properties, while displaying their unquestionable ambition. At the same time, they did not divert their attention from the general economic issues important for the Crown, such as salt mining.

As a wealthy member of the nobility, who during his life held the highest state positions, Jan of Pilcza concentrated on the foundation activity as well. It regarded mainly the territories owned by him, which, however, was not a rule. Considering the most important examples of the Pilecki's foundation seems therefore to be the key issue for presenting a complete picture of the indicated figure. This approach facilitates the noticing of the programme as well as

\footnotetext{
21 F. Kiryk, Lanckoroński Mikołaj h. Zadora (the Zadora coat of arms) (died in 1462), Polski Słownik Biograficzny, vol. 16, Wrocław Warszawa Kraków Gdańsk, 1971, p. 446.

22 S. Gawęda, Możnowładztwo małopolskie..., p. 117.

23 Ibid, p. 118; R. Trawka, Kmitowie. Studium kariery politycznej i społecznej w późnośredniowiecznej Polsce, Kraków 2005, pp. 141-145.

24 P. Węcowski, Mazowsze w Koronie. Propaganda i legitymizacja władzy Kazimierza Jagiellończyka na Mazowszu, Kraków 2004, p. 72.

25 S. Gawęda, op. cit., p. 105.

26 ZDM, 3, No. 593.
} 
ideological and religious attitude presented by Jan of Pilcza, and also getting closer to his knowledge on culture and science. These are fundamental issues, indispensable for proper understanding of the mentality of the representatives of the late medieval Polish nobility.

The earliest activity of Jan of Pilcza in this field was the confirmation dated on 6 October 1426 of the founding of St. Elizabeth's altar in the Chapel of the Blessed Virgin Mary of the Cracow Cathedral by Queen Elisabeth Granowska. Continuing his mother's work, Jan granted a fixed income in the amount of 12 grivnas (units of measure) as the altar's emolument, coming from the rent in the village of Branice ${ }^{27}$. It was meant to ensure the means of maintaining the altar. The whole undertaking may be a sign of a great attachment of Pilecki to his mother and respect for her decision, even after her death. The foundation of the altar in the metropolitan cathedral was also prestigious, due to which twenty-year-old Jan could become known to his community as a responsible and generous lord, attached to his family traditions.

Another indirect foundation, also a church one, made by Jan jointly with his sister Elisabeth, was contributing to raising the rank of the Church of Pilica in 1432 from the parsonage to the provostry. Formally, the act was performed by the Cracow bishop, Zbigniew Oleśnicki, but it is known that it resulted from the efforts made by the siblings from Pilica ${ }^{28}$. Jan and Elisabeth saw to a rich emolument paid to the church. The income from tithe in the village of Domanowice and the one collected from the peasants in Załęcze and the fields of the manor house in Pilice, were used for its needs. Additionally, the vicars received half of the tithe coming from the Łośnica and 14 silver grivnas per year from the bourgeois state in Pilica. Butchers from Nowa Pilica were supposed to give them annually 2 stones of tallow. The source list of goods, constituting the emoluments of the Pilica provostry, is closed by the church collection, and also the immovable goods that included a house and 4 gardens. The document of Bishop Oleśnicki defines the income of the provost himself as well, constituting the amount of the sheaf tithe from the village of Sławnowo, tithing collected from the smallholders of Old Pilica, tithing from Dłużec, Lgota, Wolbrom (royal good), field tithing from towspeople of Bydlin, Kąpiela, Przyłubsk and Żedów as well as, in the case of vicars, from the Pilica manor fields. Additionally, the provost's emolument included collections from Christmas calls in the parish, one third of the church collection and 6 stones of tallow, offered by the butchers from Pilica. The immovable goods, belonging to the provost, included a grange in Old Pilica, a pond and a pool with a bed, 7 gardens and two meadows. A significant privilege of the Pilica provost was also the right to carry out free logging in the surrounding forest ${ }^{29}$. The rich emolument of the provostry established by bishop Oleśnicki, standing in opposition to Pilecki, makes one reflect on the aforementioned Hussitism, to which the members of the iuniores faction and the confederates of the Spytko of Melsztyn were supposed to be inclined. In the light of the presented sources, the accusation of heresy against Jan of Pilcza, seems to be highly unfounded. He supported the church development on the lands under his administration. It underlined his efforts to establish the provostry in Pilica. It is possible that the indicated action was motivated by the desire to develop the religious life of the inhabitants and the pastoral service of the clergy at a higher

27 Zbiór dokumentów katedry i diecezji krakowskiej (hereinafter ZDK), 2, ed. S. Kuraś, Lublin 1973, No. 270.

28 Ibid, No. 309; H. Błażkiewicz, Pilica: zarys dziejów miejscowości, Kraków 1992, p. 145.

29 ZDK, 2, Lublin 1973, No. 309; H. Błażkiewicz, op. cit., p. 145. 
level ${ }^{30}$. The co-operation between Jan and his sister in the issue of the emolument of the provostry in Pilica may exemplify common views of the siblings and their good relationship.

In 1450, Jan of Pilcza confirmed the bestowal of rent from the salt mine to the hospital of St. Hedwig in Bocheń. The indicated foundation of Pilecki was also a repetition of the emolument paid by his mother - Queen Elisabeth. In the document containing the conditions for the emolument, Jan reserved for himself the right to care for and manage the hospital as well as the right to patronage over the hospital ${ }^{31}$. It sets Pilecki up as a continuator of his mother's ideological and social programme.

After taking up the office of the Cracow voivod, Jan of Pilcza endowed the church and the parish in Chmielnik with his properties ${ }^{32}$. The parish was given the freedom to use the resources of the local rivers and forests as well as pastures. The clergymen could also use mills and had the right to collect meal offerings. The parson in the parish was to receive rye and oats from peasants in one log from the field. Moreover, Jan endowed the church with two agricultural plots of land ${ }^{33}$. Another church endowed by Jan was the temple in Borek Stary which was given one plot of land in the village of Nowy Borek ${ }^{34}$. It provides a possibility to state that Pilecki was keenly interested in strengthening of the Church at its lowest levels. Granting emoluments to local parishes did not bring such popularity as monastic foundations, which may partially display the motivation of Pilecki, who was interested in efficient functioning of less exposed units of the church administration. The emolument granted to the parish church in Kosin by Jan of Pilcza constitutes a similar example ${ }^{35}$.

Another significant church function of Jan of Pilcza was the establishment of the mansionary college at the parish church in Tyczyn in 1454. It was devoted to the Blessed Virgin Mary and consisted of three members (vicars) and a rector. Pilecki endowed it with the income of 22 grivnas of annual rent, from the village of Budziwój ${ }^{36}$. The fact should be perceived as a manifestation of his lively concern for spiritual education and the future of the Church, as well as a proof of attachment to the cult of Mary, spread at that time among the nobility of Małopolska. In 1466, Jan of Pilcza founded the construction of a new, brick church for Tyczyn ${ }^{37}$. When combined with his economic efforts undertaken for the benefit of the indicated town, it can be noticed that Pilecki took special care for the town. Proper management and city foundations resulted probably in an increase in the number of inhabitants and visiting merchants, which directly impacted the development of the centre. In the context of the activity of other members of the young nobility faction regarding the development of the parish network, one can also notice their attachment to this type of

\footnotetext{
$30 \quad$ Ibid, p. 147.

31 ZDK, 2, Lublin 1973, No. 546; Korespondencja żupnika krakowskiego Mikołaja Serafina z lat 1437-1459, eds. W. Bukowski, T. Płóciennik, A. Skolimowska, Kraków 2006, p. 99.

32 ZDM, 5, 1970, No. 1431.

33 Ibid.

34 A. Festnacht, Słownik historyczno-geograficzny ziemi sanockiej w średniowieczu, Brzozów 1991, p. 49.

35 F. Sikora, Pilecki (Granowski) Jan h. Leliwa (ok. 1405-1476), Polski Słownik Biograficzny, vol. 26, Kraków Wrocław 1981, p. 258.

36 F. Kiryk, S. Mateszew, op. cit., p. 52.

37 Ibid, p. 67.
} 
activity. An example of the church in Batorze, founded together with the parish school by Andrzej Tęczyński, is worth mentioning here ${ }^{38}$.

While analysing the foundation activity of Jan of Pilcza, the book collection compiled by him in his residence, is worth noting. The issue of recreating its contents may be used as a theme for separate research. However, the fact of the existence of a library in the castle of Pilica is worth noting first of all. Biernat of Lublin, an outstanding humanist and a writer, who for almost 20 years served as the court doctor, chaplain and secretary of the Pilica Castle, informs about it in his records at the beginning of the 16th century. His patron was the grandson of Jan of Pilcza - also Jan (III). Recalling the stay at his court, Biernat wrote that he spent there a lot of time reading books, many of which were at the Pilica castle, which was supposed to be conducive to Biernat's work ${ }^{39}$. The publications he found there included, inter alia, the History of Three Kings (Historia Trium Regum) by Jan of Hildesheim. It can be said with a high degree of probability that Biernat, using the Pilica book collection, had an opportunity to come across works collected by the grandfather of his guardian and patron ${ }^{40}$. It is unlikely that Jan III Pilecki himself managed to create a library that Biernat could describe with such admiration. The indicated conclusion might certify the intellectual level of the castellan of Cracow, Jan of Pilcza, and his need to contact with culture. The attention paid by Pilecki to expanding the influence of Latin culture in his community is also evidenced by the fact that an Italian - Jan Fabiani - was employed as his secretary ${ }^{41}$. Considering the fact that in the middle of the 15th century the preparation of foreigners as their co-workers was not a popular phenomenon among the laity, it can be concluded that Pilecki supported the idea of drawing on interstate contacts also in a narrower, family dimension. The indicated factors complement the image Jan of Pilcza as an enlightened and ambitious man who, having achieved political success, did not forget about the development of material and spiritual culture in his surroundings. This feature was also inherited from him by his descendants, who supported Polish humanism in the Renaissance era.

Although Jan of Pilcza himself did not probably found any monastery from scratch, it is known that his companions from the iuniores faction were very active in this field. Main reasons for undertaking this kind of activities by the mighty were the devotional desires and the commemorative functions that a given gathering was to perform with reference to its founder ${ }^{42}$. The presence of the monastery determined of schooling and education in a given area. It had an impact on the development of culture, among other things, through the monastery schools, libraries and scriptoria run by the monks ${ }^{43}$. All the aforementioned factors resulted in the fact that the representatives of the nobility frequently established new monastic foundations and endowed the existing ones. It is impossible to see the common

\footnotetext{
38 J. Kurtyka, Tęczyńscy. Studium z dziejów polskiej elity możnowładczej w średniowieczu, Kraków 1997, p. 498; ZDM, 3, No. 849 .

39 „Aetas ista potissimum in legendo mihi decursa, diutie bona librorum copia et quies in Pylca”. See; S. Grzeszczuk, Jam byt Biernat z Lublina (Wstęp do wydania Ezopa Biernata z Lublina), Kraków 1997, pp. 13-15.

40 Ibid, p. 16.

${ }^{41} \quad$ F. Sikora, op. cit., p. 258.

42 Z. Zyglewski, Klasztorne fundacje możnowładztwa koronnego w okresie jagiellońskim. zarys problematyki, in: Klasztor w społeczeństwie średniowiecznym i nowożytnym, eds. M. Derwich, A. Pobóg-Lenartowicz, Opole Wrocław 1996, p. 134.

43 Ibid, pp. 140-141.
} 
features for the faction members in the indicated area of activity, as was the case with some other families at that time ${ }^{44}$. The foundation achievement of Jan Hińcza of Rogów is the most impressive in this context. His two most famous foundations were the monasteries of: the canons regular in Krzepice and Bernardines in Koło ${ }^{45}$. The foundation of the canon monastery in Krzepice is particularly interesting in the context of political and personal affection of Hińcza to the Queen Zofia Holszańska. While founding the monastery, Rogowski wanted the monks to pray for the soul of the queen. The importance of the intention for him was underlined by the fact that he had asked for it before asking for praying for him and his family ${ }^{46}$. Moreover Hińcza granted emoluments to monastic communities. The most important ones include the transfer of income from salt mines to the maintenance of the Cracow Bernardines of St. Agnes, as well as granting emoluments to the Bernardine monastery in Cracow, the canons regular in Mstów, the Order of the Holy Sepulchre of Miechów and the Dominicans of the Holy Trinity in Cracow ${ }^{47}$. Until recently, the latter ones have been associated with the charity work of the Tęczyński family but the relations between the indicated monastery and the family developed only at the end of the 15th century, which excluded the possibility of the existence of its connections with the person of Andrzej Tęczyński ${ }^{48}$. Among the monasteries endowed by iuniores there were also Bernardines of Opatów, whose benefactors were Dziersław and Jan Rytwiański, responsible for founding the altars of the Holy Innocents in the Sandomierz collegiate church ${ }^{49}$.

The endowment was often connected with the establishment or transfer of a right of patronage. It was the case with, among others, the parish church in Koniusza, where one of patrons was Piotr Kurowski, the father-in-law of Jan of Pilcza ${ }^{50}$. In 1460, he endowed the missionaries of Kurów with 20 grivnas from annual rent of the village in Brzozowa ${ }^{51}$. He also brought about the payment of the emolument to Lublin Dominicans in the same year ${ }^{52}$. Cracow Augustinians however, were the beneficiaries of the emoluments of Mikołaj Lanckoroński of Brzezie ${ }^{53}$. The aforementioned Sandomierz altarists were endowed with the amount of 40 grivnas by the Rytwiański brothers coming from the municipal duty. They additionally donated them with valuable liturgical vessels, robes and a three-volume postilla, a mass and a two-volume parchment Bible, at the same time transferring the rights of patronage over the

\footnotetext{
44 At the end of the 15 th century there was a family dependence on the monastery foundations. Individual congregations were supported by individual families. The indicated phenomenon concerned, among others, the Oleśnicki, Oporowski and Koniecpolski families. See: Z. Zyglewski, op. cit., p. 139.

45 B. Czwojdrak, Rogowscy herbu Działosza - podskarbowie królewscy, Katowice 2002, pp. 151-156; Eadem, Zofia Holszańska. Studium o dworze i roli królowej w późnośredniowiecznej Polsce, Warszawa 2012, p. 139.

46 Ibid.

47 Eadem, Rogowscy..., pp. 156-158.

48 M. Zdanek, O związkach rodziny Tęczyńskich z konwentem dominikanów krakowskich, in: narodziny Rzeczpospolitej. Studia z dziejów średniowiecza i czasów wczesnonowożytnych, eds. W. Bukowski, T. Jurek, vol. 1, Kraków 2012, p. 456.

49 W. Fałkowski, Rytwiański Dziersław h. Jastrzębiec (1414-1478), Polski Słownik Biograficzny, vol. 33, Wrocław Warszawa Kraków 1991-1992, p. 587.

50 ZDM, 5, No. 1318.

51 Słownik historyczno-geograficzny województwa lubelskiego, ed. S. Kuraś, Warszawa 1983, p. 40.

52 Ibid, p. 133.

53 F. Kiryk, Lanckoroński Mikołaj h. Zadora..., p. 446.
} 
altars to the Faculty of Liberal Arts of the University of Cracow ${ }^{54}$. Dziersław of Rytwiany bequeathed a copy of the Bible to the Cracow Chapter in his will ${ }^{55}$. Hospitals, such as the Holy Spirit Church in Cracow, endowed by Jan Hańcza of Rogów, who crowned his activity with financing the construction of the Hińczów Chapel in the Cracow Cathedral ${ }^{56}$, were also popular among the founders.

The activity of the representatives of the faction of iuniores, including Jan of Pilcza, in the field of foundation and economic activity was a significanrt element of the implementation of the ideological and political programme of the group. Its profile constitutes a significant complementation of the picture of the young nobility faction history, founded on the basis of the 1439 act of the Spytko of Melsztyn confederation. Deepening research in this area may bring us closer to a more complete presentation of the biographies of individual members of the group. In this context, a synthetic presentation of the activities of one of the most interesting members of the opponent party of Zbigniew Oleśnicki, the Cracow castellan, Jan of Pilcza, induces the development of reflections on the real attitude of this part of the representatives of the late medieval nobility of the Crown of the Kingdom of Poland, the group to which until now, insufficient attention has been paid in contemporary historiography.

\section{The castellan of Cracow - the economic and foundation activity of Jan of Pilcza. The profile against a background of the selected Iuniores faction representatives' activity Summary}

The article presents the most important examples of castellan Jan from Pilcza economic and foundational activity in the context of other Iuniores faction members achievements. The text elaborates endowments and ways of managing the lands by Jan from Pilcza and members of the young nobles party. It contains also some observations about common points of iuniores actions - groups known as the main part of the opposition against bishop Zbigniew Oleśnicki. Recognition of these activities profiles is helpful in better understanding the ideological and political attitude of medieval Crown of Polish Kingdom noble elite representatives, who were participants of Spytko from Melsztyn confederetion. The Jan from Pilcza biography is an example of political and social advancement in times of Władysław III and Kazimierz Jagiellończyk reigns. His economic activity had been mainly based on profits from his lands and developing, inter alias, trade markets. Privileges which he dedicated for Tyczyn and Łańcut confirm the observed trend. Also mining was an economy branch developed in described region by Jan from Pilcza. The mentioned activity had a positive impact on defensive capability of Crown of Polish Kingdom. Jan from Pilcza's economic activities, such as salt-mining organizing, could be viewed as similar to other iuniores. In that context it is necessary to highlight that iuniores chantry actions, endowments and a lot of connections between them and catholic Church are denying the thesis about Hussitism among this political faction representatives.

\footnotetext{
54 W. Fałkowski, Rytwiański Dzierstaw..., p. 587.

55 Ibid.

56 B. Czwojdrak, Rogowscy..., pp. 160-165.
} 
Keywords: Jan from Pilcza, Iuniores, nobles, the Middle Ages, endowments

A note about the Author: Jan Szyrwiński - a PhD student, a graduate of the Faculty of History and Social Sciences of the Cardinal Stefan Wyszyński University, Warsaw. His research involves the history of medieval magnates and political history. 